\title{
Media Framing on the Palestine-Israel Conflict
}

\author{
Harun Arrosyid ${ }^{1 *}$, Umi Halwati $^{1}$ \\ ${ }^{1}$ Prof. K.H. Saifuddin Zuhri State Islamic University, \\ Purwokerto, Indonesia
}

Article Information

Submitted June 20, 2021

Revised August 05, 2021

Accepted August 28, 2021

Published October 30, 2021

\begin{abstract}
The media is a medium for acquiring information, presenting factual information, data accuracy, and holding the responsibilities of news writers and media ethics. With the media's significant role in constructing information and news, the media should be unbiased. However, the media has its pattern of publishing news, such as the conflict between Israel and Palestine. These contrasts can be seen from the various framing between one media and another, such as the different points of view of news writing, the title, and the images displayed. The purpose of this study is to examine how the media reconstructs the reality of the Palestinian-Israeli conflict. The mass media studied were kompas.com and republika.co.id. The research method uses qualitative research with framing analysis of William A. Gamson and Andre Modigliani. Utilizing framing analyst William A. Gamson, the reality emerges in device framing devices and reasoning devices. The results showed that republika.co.id highlighted the news of the United Nations Security Council, which failed to handle the Israeli-Palestinian conflict and tried to raise the image of Palestine, which desperately needed international support. Meanwhile, kompas.com reported on the conflict more neutrally, reporting the United Nations Security Council's exertions to stop the conflict.
\end{abstract}

Keywords: Media Framing, Palestine-Islael Conflict, Republika.co.id, kompas.com

\section{Introduction}

The mass media represents the renewal of the social subsystem formed to meet the public's need for information. Mass media can influence and change people's thoughts and perceptions. Society needs accurate mass media publications, up-to-date, beneficial, and responsible for a better social life. (Wahid, 2016).

In essence, the media must be neutral and maintain their ideology because the mass media is a system of beliefs and values of representation in a media. Vivian (2008) explains that the media is a neutral medium in conveying information or messages. However, at present, mass media observers are concerned about information bias.

The Palestinian-Israeli conflict is one piece of overcrowded information that gets wide public attention. The conflict resulted from the UN's decision to divide the Palestinian territories into Israeli Jews and Palestinian Arabs. Thus, causing protests from both parties who feel dissatisfied. This decision causes a prolonged conflict (Elvira, 2013). The Palestinian-Israeli conflict itself

*Author Correspondence: Harun Arrosyid, Prof. K.H. Saifuddin Zuhri Islamic State University, email, Jl. A. Yani No. 40-A Purwokerto, Jawa Tengah 53126, Indonesia

Copyright (C) 2021 Harun Arrosyid,Umi Halwati 
seems to be eternal. The suspected cause is the lack of international law enforcement in providing sanctions for countries that violate the provisions of international law. The conflict has violated applicable humanitarian law, and war crimes committed by Israel should be immediately followed up by international law.

The conflict between Palestine and Israel is never stopped topic discussed by the mass media, both print and electronic media. The conflict between the two countries is one of the exciting factors for news coverage. The discussion of the Palestinian-Israeli conflict has a broad spectrum because the conflict between the two countries is more comprehensive than territorial boundaries, but more extensively, involving religion and ideology.

The bad news is good news. Conflict is one of the news values used by the mass media. The conflict will increasingly attract the interest of the reader. Mass media is a business to make a profit, so the mass media should represent attractive news to the public, including conflict news (Biagi, 2010).

In Indonesia, kompas.com and republika. co.id is the online media platforms that netizens access the most and significantly influence readers' opinions. Apart from broad reach, kompas.com and republika.co.id have various economic, political, and ideological interests. Therefore, it is interesting to examine how the news about the PalestinianIsraeli conflict is displayed in the two media with different background, aim, and scope. Each media has its way of displaying news according to its principles, ideology, and interests. This difference can be detected from the different framing between one media and the different points of view on news writing style, title writing, and the images displayed. Based on this background, this study aims to analyze the framing of the Palestinian and Israeli conflicts on the kompas.com and republika.co.id media.

\section{Method}

This research is qualitative research using the framing analysis of William A Gamson and Andre Modigliani to connect the discourse in two different media regarding an event. Gamson sees media discourse as consisting of several packages through the construction of a phenomena/occurrence. In this study, two framing devices are used, explicitly framing devices and reasoning devices. Framing devices analyze metaphors (Metaphors) of interesting, contrasting, prominent phrases in a discourse (Catchphrase), linking frames with examples, descriptions that clarify the frame (Exemplar), depicting an issue. Connotative (Depiction) and images, supporting graphics (Visual image). Reasoning devices analyze causality or cause and effect (Roots), the basic premise (Appeals to principle), and the consequences obtained from the frame (Consequences). The framing device aims to examine the framing on republika.co.id and kompas.com detailly regarding the PalestineIsrael conflict for the period 17-18 May 2021.

\section{Result}

This study analyzes the two most popular online media in Indonesia, republika. co.id and kompas.com, which present news framing of the Palestine-Israel conflict for 17-18 May 2021. The list of Palestine-Israel conflict content news as the research focus is presented in Tables 1 to 3 below: 
Table 1.

Reporting on the Palestine-Israel Conflict for 17-18 May 2021 by republika.co.id and kompas.com.

\begin{tabular}{cll}
\hline \multicolumn{1}{c}{ Date } & \multicolumn{1}{c}{ republika.co.id } & \multicolumn{1}{c}{ kompas.com } \\
\hline May 17, 2021 & $\begin{array}{l}\text { Organization of Islamic Cooperation } \\
\text { (OKI) State: United Nation Security } \\
\text { Council Has Failed to Protect Pales- } \\
\text { tine }\end{array}$ & $\begin{array}{l}\text { United Nations Security Council Has } \\
\text { Not to Take Action Yet Regarding Pales- } \\
\text { tine-Israel Conflict }\end{array}$ \\
\hline May 18, 2021 & $\begin{array}{l}\text { Palestine Urges United Nation to } \\
\text { Stop Israel's Crimes against Children }\end{array}$ & $\begin{array}{l}\text { Israel-Palestine Today: The Worst At- } \\
\text { tack on Gaza, United Nations Security } \\
\text { Council Helds Emergency Meeting }\end{array}$ \\
\hline
\end{tabular}

Source: Researcher Processed Data, 2021

Table 1 explains that on May 17, 2021, Republika.co.id presented news about "State of the Organization of Islamic Cooperation: The United Nations Security Council has failed to protect Palestine." Meanwhile, kompas. com presented news that "the UN Security Council has not taken any action regarding the Palestinian-Israeli conflict." On May 18,
2021, republika.co.id reported again that "Palestine Urges the United Nations to Stop Israel's Crimes against Children." Meanwhile, kompas.com reported that "Israel-Palestine Today: The Worst Attack on Gaza, the United Nations Security Council held an Emergency Meeting."

Table 2. Framing Differences in News Edition May 17, 2021, Republika.co.id and kompas.com

\begin{tabular}{|c|c|c|}
\hline Online Media & republika.co.id & kompas.com \\
\hline Frame & $\begin{array}{l}\text { UN Security Council Has Failed to } \\
\text { Protect Palestine }\end{array}$ & $\begin{array}{l}\text { UN Security Council Has not to Take } \\
\text { Action Yet }\end{array}$ \\
\hline Metaphors & $\begin{array}{l}\text { The sentence "failed to protect Pal- } \\
\text { estine" symbolizes that the United } \\
\text { Nations has failed to control Israeli } \\
\text { attacks in the Palestinian Gaza Strip } \\
\text { as the person in charge of interna- } \\
\text { tional security. }\end{array}$ & $\begin{array}{l}\text { Not taking action yet means that the } \\
\text { United Nations as the person in charge } \\
\text { of international security, is still silent } \\
\text { and has not taken decisive action to } \\
\text { stop the Palestinian-Israeli conflict, } \\
\text { which has caused many deaths, espe- } \\
\text { cially Palestinians. }\end{array}$ \\
\hline Catchphrases & $\begin{array}{l}\text { Failing to protect Palestine in the } \\
\text { headline by emphasizing the word } \\
\text { "fail," which indicates that the United } \\
\text { Nations Security Council is incompe- } \\
\text { tent to resolve the Palestinian-Israeli } \\
\text { conflict. }\end{array}$ & $\begin{array}{l}\text { Not taking action yet in the headline, } \\
\text { "action" confirms that the United Na- } \\
\text { tions Security Council is still silent and } \\
\text { allows the Palestinian-Israeli conflict, } \\
\text { which has caused many deaths. }\end{array}$ \\
\hline Exemplar & $\begin{array}{l}\text { republika.co.id stated that the Or- } \\
\text { ganization of Islamic Cooperation } \\
\text { considers the United Nations Secu- } \\
\text { rity Council to have failed to assume } \\
\text { its responsibility to stop the Israeli } \\
\text { aggression in Gaza. }\end{array}$ & $\begin{array}{l}\text { kompas.com stated that the delegates } \\
\text { who attended the United Nations } \\
\text { Security Council meeting regretted the } \\
\text { deaths of civilians and material losses, } \\
\text { but the United Nations Security Council } \\
\text { was still incapable of taking any action. }\end{array}$ \\
\hline
\end{tabular}




\begin{tabular}{|c|c|c|}
\hline Depiction & $\begin{array}{l}\text { The Organization of Islamic Cooper- } \\
\text { ation made exertions by holding an } \\
\text { extraordinary meeting of the United } \\
\text { Nations Organization of Islamic Co- } \\
\text { operation to protect the Palestinian } \\
\text { people. }\end{array}$ & $\begin{array}{l}\text { The United Nations Security Council } \\
\text { made exertions by holding a meeting } \\
\text { to discuss the escalation of the Pal- } \\
\text { estinian-Israeli conflict. The Chinese } \\
\text { ambassador presiding over the meeting } \\
\text { will continue to communicate with all } \\
\text { United Nations Security Council mem- } \\
\text { bers to take fast and unified action. }\end{array}$ \\
\hline $\begin{array}{l}\text { Visual } \\
\text { Images }\end{array}$ & $\begin{array}{l}\text { Image of a retaliatory rocket that } \\
\text { launched from Gaza to Israel. }\end{array}$ & $\begin{array}{l}\text { Image of a virtual meeting of the United } \\
\text { Nations Security Council discussing the } \\
\text { Palestinian-Israeli conflict. }\end{array}$ \\
\hline Roots & $\begin{array}{l}\text { Israel's pounding of Palestinian Gaza } \\
\text { has killed } 197 \text { people. Seventeen } \\
\text { people were killed in the west line as } \\
\text { Palestinians protested against Israel. } \\
\text { Some Palestinians died because of } \\
\text { protesting against Israel, so Israel } \\
\text { killed them. }\end{array}$ & $\begin{array}{l}\text { During the United Nations Security } \\
\text { Council meeting, it was explained that } \\
\text { the Palestinian and Israeli diplomats } \\
\text { who were invited to the meeting at- } \\
\text { tacked each other. The United Nations } \\
\text { Security Council had to communicate } \\
\text { with other members to make decisions } \\
\text { with one vote quickly. So due to mutual } \\
\text { attacks between diplomats, the United } \\
\text { Nations Security Council has not yet de- } \\
\text { cided on the Palestinian-Israeli conflict. }\end{array}$ \\
\hline $\begin{array}{l}\text { Appeals to } \\
\text { Principles }\end{array}$ & $\begin{array}{l}\text { The Organization of Islamic Coop- } \\
\text { eration explained that the Al-Aqsa } \\
\text { Mosque is a red line for Muslims so } \\
\text { that its security and stability must be } \\
\text { maintained. }\end{array}$ & $\begin{array}{l}\text { The United Nations Security Council as } \\
\text { the person in charge of international } \\
\text { security and peace must immediately } \\
\text { take action in dealing with the Pales- } \\
\text { tinian-Israeli conflict, which has caused } \\
\text { many deaths. }\end{array}$ \\
\hline Consequences & $\begin{array}{l}\text { As an organization of Islamic cooper- } \\
\text { ation, OKI urges the United Nations } \\
\text { Security Council to protect Muslims } \\
\text { in Gaza, Palestine, who are increas- } \\
\text { ingly becoming victims of the Pales- } \\
\text { tinian-Israeli conflict. }\end{array}$ & $\begin{array}{l}\text { As a result of the United Nations Secu- } \\
\text { rity Council has not taken action, the } \\
\text { victims of the Palestinian-Israeli conflict } \\
\text { are increasing. }\end{array}$ \\
\hline
\end{tabular}

Table 2 explains that republika.co.id's reporting on May 17,2021, through the framing and reasoning stages, emphasized reporting on the failure of the United Nations Security Council to control the conflict, resulting in many casualties. The Organization of Islamic Cooperation held an extraordinary meeting of foreign ministers of the Organization of Islamic Cooperation's members and asked the United Nations to protect Palestinians.
Meanwhile, kompas.com reporting through framing analysis and reasoning emphasizes writing on the United Nations Security Council conference to discuss the escalation of the Palestinian-Israeli conflict. The United Nations was responsible for international security is even silent and has not taken decisive action to stop the Palestinian-Israeli conflict, which has caused many deaths. 
Table 3. Differences in Framing in the News Edition 18 May 2021 republika.co.id and kompas.com

\begin{tabular}{|c|c|c|}
\hline Online Media & republika.co.id & kompas.com \\
\hline Frame & $\begin{array}{l}\text { Palestine urges United Nations to } \\
\text { stop Israeli crimes against children. }\end{array}$ & $\begin{array}{l}\text { The Worst Attack on Gaza, United } \\
\text { Nations Security Council Emergency } \\
\text { Meeting }\end{array}$ \\
\hline Metaphors & $\begin{array}{l}\text { The sentence "urgent" symbolizes } \\
\text { that there have been many deaths } \\
\text { from Palestinian civilians, includ- } \\
\text { ing children and material damage. } \\
\text { Children in Palestine have no shelter } \\
\text { from Israeli attacks. }\end{array}$ & $\begin{array}{l}\text { The sentence "emergency" symbolizes } \\
\text { that Israel's attacks have caused many } \\
\text { civilian deaths in Palestine and material } \\
\text { damage that the United Nations Securi- } \\
\text { ty Council must take action immediate- } \\
\text { ly. }\end{array}$ \\
\hline Catchphrases & $\begin{array}{l}\text { Palestine urged the United Nations in } \\
\text { the news headlines, emphasizing the } \\
\text { word "urgent," which indicates that } \\
\text { Palestine needs international assis- } \\
\text { tance to deal with attacks from Israel } \\
\text { that have claimed many Palestinian } \\
\text { civilian lives. }\end{array}$ & $\begin{array}{l}\text { "The United Nations Security Council } \\
\text { emergency meeting." By emphasizing } \\
\text { the word "emergency," the title shows } \\
\text { that the Israeli attack on Palestine is } \\
\text { getting more severe and causing more } \\
\text { deaths. The Palestinian-Israeli conflict } \\
\text { is on the rise. }\end{array}$ \\
\hline Exemplaar & $\begin{array}{l}\text { republika.co.id stated that Pales- } \\
\text { tine, through Foreign Minister Riyad } \\
\text { Al-Maliki, urged the United Nations } \\
\text { to stop Israel's crimes against Pales- } \\
\text { tinian children because of the enor- } \\
\text { mous number of children who died } \\
\text { in Palestine }\end{array}$ & $\begin{array}{l}\text { kompas.com stated that the United Na- } \\
\text { tions Security Council held an emergen- } \\
\text { cy meeting to end the Palestinian-Israeli } \\
\text { conflict, which has claimed many lives, } \\
\text { mainly Palestinian civilians. }\end{array}$ \\
\hline Depiction & $\begin{array}{l}\text { Palestine assembled exertions by } \\
\text { sending diplomacy to Foreign Minis- } \\
\text { ter Riyad Al-Maliki at the United Na- } \\
\text { tions Security Council meeting and } \\
\text { urging the United Nations to stop } \\
\text { Israel's crimes against children. }\end{array}$ & $\begin{array}{l}\text { The United Nations Security Council } \\
\text { assembled exertions by holding an } \\
\text { emergency meeting to stop the Palestin- } \\
\text { ian-Israeli conflict, which has claimed } \\
\text { many lives. }\end{array}$ \\
\hline Visual Images & $\begin{array}{l}\text { Image of Palestinian children feeling } \\
\text { the adverse effect of the Palestin- } \\
\text { ian-Israeli conflict. }\end{array}$ & $\begin{array}{l}\text { Image of the explosion that lit up the } \\
\text { night sky in Gaza due to the bombard- } \\
\text { ment of weapons from Israel. }\end{array}$ \\
\hline Roots & $\begin{array}{l}\text { The recent conflict in Gaza has es- } \\
\text { calated after the Palestinians prom- } \\
\text { ised to avenge the Israeli attacks on } \\
\text { Al-Aqsa Mosque and Sheikh Jarrah. } \\
\text { So the cause of the escalating conflict } \\
\text { between the two countries is the Pal- } \\
\text { estinian promise to retaliate against } \\
\text { Israel. }\end{array}$ & $\begin{array}{l}\text { The Israeli airstrikes pounding Gaza } \\
\text { since May } 10 \text { came after the ruling } \\
\text { Hamas fired a barrage of rockets follow- } \\
\text { ing Israeli-Palestinian clashes in East } \\
\text { Jerusalem. So the cause of increased } \\
\text { Israeli attacks due to Palestinians firing } \\
\text { rockets at Israel. }\end{array}$ \\
\hline $\begin{array}{l}\text { Appeals to } \\
\text { Principles }\end{array}$ & $\begin{array}{l}\text { The Organization of Islamic Coop- } \\
\text { eration explains that the Al-Aqsa } \\
\text { Mosque is a red line for Muslims, so } \\
\text { United Nations should defend the } \\
\text { security and stability of the mosque. }\end{array}$ & $\begin{array}{l}\text { The United Nations Security Council } \\
\text { was responsible for international peace } \\
\text { and security, strives to take immediate } \\
\text { action to resolve the Palestinian-Israeli } \\
\text { conflict }\end{array}$ \\
\hline
\end{tabular}




\begin{tabular}{lll}
\hline Consequences & $\begin{array}{l}\text { Palestine urges United Nations Se- } \\
\text { curity Council to stop crimes against }\end{array}$ & As a result of the increasing number of \\
Palestinian children victims of Israeli & Nations Security Council held an emer- \\
attacks. & gency meeting to stop the conflict. \\
\hline
\end{tabular}

Source: Researcher Processed Data, 2021

Table 3 explains that republika.co.id's reporting on May 18, 2021, through the stages of framing and reasoning, emphasizes that Palestine provokes the United Nations to stop Israel's crimes against children due to many casualties from Palestinian children. Reporting with visual images of Palestinian children feeling the adverse effect of the Palestinian-Israeli conflict supports the framing of Republika.co.id. Meanwhile, kompas.com reporting through framing analysis and reasoning, explained that the United Nations Security Council held an emergency meeting due to Israeli attacks on Palestine, causing many Palestinian civilian deaths and causing extensive damage. The United Nations Security Council should take an immediate step. In its reporting, kompas. com used a visual image of an explosion that lit up the night sky in Gaza, Palestine, to strengthen the perception and framing that Gaza Palestine was in an emergency condition and needed immediate solving.

\section{Discussion}

Mass media plays a significant role in constructinginformation or news publications. Mass media is needed as a medium to acquire information, current factual information, data accuracy, accountability from news writers, and media ethics. No element of interest or power reduces the accuracy of the news. However, with various underlying reasons, both technically, economically, and ideologically, the mass media often present the reality of the news regulated to reduce the accuracy of news (Siswanti, 2019).

The research results on republika.co.id and kompas.com in the comparable date period showed that both media described their point of view and presented the news with their respective framing of the Palestinian-Israeli conflict.

The media can display news with subjective views and objectives related to political and economic interests (Biagi, 2010). The quality of media coverage that contains conflicts between two or more parties can lead to two possibilities: expanding the escalation of the conflict and helping to resolve the conflict. The mass media are expected to reveal news based on aspects of the situation and the root of the problem to enhance the situation (Siebert, 1986).

The news presentation by the two most popular online media in Indonesia represents that the conflict between Palestine and Israel is a severe problem and should be resolved by the international organization, specifically the United Nations Security Council. The two media both desired to highlight that the Palestinian-Israeli conflict continues to escalate. However, the United Nations Security Council as the person in charge of international security has not taken decisive action to resolve the conflict so that the dead victim continues to grow.

republika.co.id tends to frame the news by highlighting the United Nations Security Council's failure to protect Palestine. The word 
"failed" used by Republika.co.id explained that the United Nations Security Council, which had the responsibility for international security, had failed and could not resolve the conflict. Israeli attacks on Palestinian Gaza have killed 197 people. Seventeen people were killed in the West Line because Palestinians protested against Israel.

Information packaged by republika. co.id is clarified with visual images in the form of rocket attacks hitting Palestine. The conclusion is that republika.co.id describes more support for Palestine. This image raises the perception that republika.co.id, the national media, supports Palestine in the conflict. republika.co.id aim to raise the image of Palestine, which is in dire need of international support. This framing results from the mass media's role as an industry that pays attention to the satisfaction of its audience (Hamad, 2004). republika.co.id also has a political interest to get more support from its community, especially the Muslim community, to increase its media revenue. The attitude shown by republika.co.id follows Mc Quail's theory that the media will construct news according to the dominant class, the audience.

Meanwhile, kompas.com, with the United Nations Security Council's news frame, has not taken action on the Palestinian-Israeli conflict. kompas.com emphasized the news frame of the United Nations Security Council meeting to discuss the Palestinian-Israeli conflict despite not taking significant action, so the victims' death persisted in increasing. kompas.com emphasizes its role as a neutral mass media, framing the news by informing the development of the conflict and the steps of the United Nations Security Council in overcoming the Palestinian-Israeli conflict without siding with one of the parties. This framing is supported by a visual image of the United Nations Security Council's visual meeting discussing the Palestinian-Israeli conflict.

\section{Conclusion}

News of the Palestinian and Israeli conflicts are international news that is packaged and framed differently by republika. co.id and kompas.com. The characteristics of the media influence its framing. The reality of occurrences is framed in the framing device and reasoning device. republika.co.id highlighted the news that the United Nations Security Council failed to deal with the IsraeliPalestinian conflict and tried to raise the image of Palestine, which desperately needs international support. Meanwhile, kompas. com reported the conflict neutrally.

\section{Bibliography}

Biagi, S. (2010). Media/Impact:AnIntroduction to Mass Media (9th Edition ed.). Jakarta :Penerbit Salemba Humanika.

Christiyaningsih. 18 Mei 2021. Palestina Desak PBB Hentikan Kejahatan Israel pada Anak-anak. republika.co.id. diakses melalui https://www.republika.co.id/ berita/qtajte144731105/palestinadesak-pbb-hentikan-kejahatan-israelpada-anakanak

Elvira Dewi Ginting. (2013). Konflik Israel-Palestina Ditinjau Dari Hukum Internasional. Jurnal Saintech, 05(01). https://doi.org/ISSN No. 2086-9681

Goffman, E. (1986). Frame analysis an essay on the organization of experience. Northeastern University Press. 
Hamad, Ibnu. 2004. Konstruksi Realitas Politik Dalam Media Massa. Sebuah Studi Critical Discourse Analysis Terhadap BeritaBerita Politik. Penerbit Granit. Jakarta

Iswara Aditya J. 18 Mei 2021. Israel-palestina Hari ini: Serangan terparah di Gaza, DK PBB Rapat Darurat. kompas.com. diakses melalui https://www.kompas.com/ global/read/2021/05/18/204806370/ israel-palestina-hari-ini-seranganterparah-di-gaza-dk-pbb-rapatdarurat?page $=$ all

Mabruroh. 17 Mei 2021. Negara OKI: DK PBB Telah Gagal Lindungi Palestina. republika.co.id. diakses melalui https://www.republika.co.id/berita/ qt8oub377/negara-oki-dk-pbb-telahgagal-lindungi-palestina

$\begin{array}{crrr}\text { Rizal jawahier } & \text { G. } 12 & \text { Mei } & \text { 2021. Dewan } \\ \text { Keamanan } & \text { PBB } & \text { Belum } & \text { Ambil } \\ \text { Tindakan } & \text { Terkait } & \text { Konflik Palestina- }\end{array}$
Israel. kompas.com. diakses melalui https: / /www.kompas.com/tren / $\mathrm{read} / 2021 / 05 / 17 / 082700265 /$ dewankeamanan-pbb-belum-ambil-tindakanterkait-konflik-palestina-israel?page=all

Siebert, P. \& S. (1986). "Empat Teori Pers". Jakarta:Intermasa.

Siswanti, N. (2019). Analisis Framing Media: Studi Komparatif Media Online "Cnn" dan "Kompas" Terkait Fenomena Kemanusiaan di Al-Aqsa Periode 20-23 Juli 2017. Jurnal Riset Komunikasi, 2(2), 110-125.

Vivian, J. (2008). Teori Komunikasi Massa, (8th Edition ed.). (T. W. B.S, Trans.). Jakarta :Pearson Education.

Wahid, U. (2016). Komunikasi Politik: Teori, Konsep, dan Aplikasi pada Era Media Baru. Bandung: Simbiosa Rekatama Media. 